DOI: $10.14451 / 1.172 .145$

\title{
ВЗАИМООТНОШЕНИЯ РОССИИ И ТУРЦИИ В ЭНЕРГЕТИЧЕСКОМ СЕКТОРЕ
}

\author{
(C) 2019 Белогорцева Нина Андреевна \\ Факультет экономики и финансов топливно-энергетического комплекса \\ Финансовый университет при Правительстве Российской Федерации, Россия, Москва \\ E-mail: nab9919@gmail.com
}

В статье анализируется динамика развития отношений между Россией и Турцией в XXI веке в энергетическом секторе. Описывается реализация ключевых совместных проектов двух государств. Сделан вывод о том, что с начала XXI века наблюдался переход от кооперации к кооптации, а затем возвращение к кооперации.

Ключевые слова: энергетический сектор, взаимоотношения государств, реализация проектов, кооперация, сотрудничество, энергетические проекты.

Двустороннее сотрудничество России и Турции в энергетическом комплексе началось в середине XX века. Если рассматривать промежуток времени, начиная с XX века, то отношения между Россией и Турцией не всегда были идеально гладкими. Были периоды и конфронтации, и кооперации. Эти страны соединены крепкими узами не только в энергетическом секторе, но и в других отраслях экономики в целом. Причём политический фактор в отношениях между государствами играет важную роль.

Чтобы понять, как и почему развиваются отношения между Россией и Турцией в энергетическом секторе, необходимо обратиться к истории.

В 1967 г. было подписано соглашение «О поставках оборудования, материалов и оказании Советским Союзом Турции услуг по строительству некоторых промышленных предприятий и условиях их оплаты» $[1,45]$. В соответствии с ним были реализованы такие крупные проекты, как строительство нефтеперерабатывающего завода в Алиага (г. Измир), строительство ТЭЦ в Сейитомере. Это и явилось отправной точкой сотрудничества двух государств в энергетической сфеpe.

18 сентября 1984 г. был заключен договор «О поставках природного газа из СССР в Турцию» $[1,47]$. Соглашение послужило основой нового сотрудничества между двумя странами. В июне 1987 г. начались первые поставки голубого топлива из Советского Союза газа в Турцию. Для транспортировки газа был построен Трансбалканский газопровод, который проходил через территорию государств Румынии и Болгарии.

Что касается взаимоотношений между го- сударствами в XXI веке, то их развитие было определено 15 декабря 1997 года. Именно в этот день Правительство Российской Федерации и Правительство Турецкой Республики заключили договор о сотрудничестве в области энергетики. Главное внимание уделялось проекту по расширению поставочных мощностей природного газа (из России в Турцию) до 14 млрд. куб. м, а затем и до 30 млрд. куб. м [6].

Для скорейшего достижения указанной выше цели в 1998 г. был подписан долгосрочный контракт между турецкой компанией «Боташ» и российской «Газпром» на поставку по Трансбалканскому газопроводу дополнительного объёма 8 млрд. куб. м природного газа в год вплоть до 2022 г. [7].

Также для увеличения поставок газа в Турцию стороны подписали соглашение о внедрении интенсивных технологий и осуществления всех необходимые инвестиции на территориях обоих государств для строительства газораспределительных сетей и газо-трубопроводов. Все эти меры дали мощнейший толчок для создания соглашения о поставке газа из России в Турцию по дну Чёрного моря. Так началось строительство газопровода «Голубой поток», пропускная мощность которого составляет 16 млрд. куб. м в год [6]. Страны условились о поставке природного газа в Турцию в течение 25 лет, начиная с 2003 года. Объёмы поставок были определены следующим образом: в 2003 г. в Турцию поставить 2 млрд. куб. м, а с 2004 года увеличивать поставки на 2 млрд. куб. м ежегодно - до 16 млрд. куб. м газ в год. Полные объёмы поставок представлены в табл. 1.

Президент РФ В.В. Путин назвал запуск тру- 
Таблица 1. Объёмы поставок газа по «Турецкому потоку», млрд. $\mathbf{M}^{3}$

\begin{tabular}{|c|c|c|c|c|c|c|c|c|c|c|c|c|}
\hline 2003 & 2004 & 2005 & 2006 & 2007 & 2008 & 2009 & 2010 & 2011 & 2012 & 2013 & $\ldots$ & 2017 \\
\hline 2 & 3,2 & 5 & 7,5 & 9,5 & 10,1 & 9,8 & 8,1 & 14 & 14,7 & 13,7 & & 15,8 \\
\hline
\end{tabular}

Источник: составлено автором по данным ВР [5]

бопровода «Голубой поток» еще одним шагом к формированию единого энергетического пространства Европы. Алексей Миллер, председатель правления российской компании «Газпром», в свою очередь подчеркнул, что после запуска трубопровода «Голубой поток» транспортные риски практически исчезли, связанные с политической обстановкой. [8]. Это объясняется тем, что голубое топливо, минуя посредников в виде третьих стран, напрямую отправляется из России в Турцию.

В отдельные периоды поставляемые суточные объемы, практически соответствуют уровню установленной пропускной мощности. Данная особенность связана с тем, что Турция сталкивается с неисполнением Ирана по поставке природного газа. Так, «Газпром», идя навстречу турецкой стороне, увеличивает прогон топлива по трубам, компенсируя эти недопоставки. [4, стр. 32].

Совокупная стоимость проекта равняется 3,2 млрд. долл. [6]. Проект «Голубой поток» стал не только первым уникальным сооружением, не имеющим аналогов, но и крупнейшим капиталовложением России. Более того, успешная реализация проекта способствовала расширению объемов экспорта российского газа в Турцию, благодаря чему Турция стала одним из крупнейших партнеров Газпрома. Таким образом, «Голубой поток» выгоден не только Турции, которой необходим природный газ, но и России. Данный проект является доказательством кооперации двух государств.

Начиная с 2008 г. Турция занимает в Европе второе (после Германии) место по объёмам потребления российского природного газа. В то же время, Россия занимает первое место среди импортёров газа в Турцию. В 2015 году доля российского газа составляла $62 \%$. В данной таблице представлена динамика поставок российского газа в Турцию. В период с 2011 по 2015 г. объём поставок газа особенно велик (табл. 2).
Турция так или иначе пытается добиться ценовых льгот при оплате российского газа. Например, в конце 2011 г. Турция дала окончательное разрешение российской компании «Газпром» на строительство в своей исключительной экономической зоне в Чёрном море газопровода «Южный поток» [3, стр.205]. Также в конце 2011 г. она заявила о своём отказе продлить действие соглашения о поставках газа по Трансбалканскому газопроводу по принципу «бери или плати».

В 2015 году политический фактор сыграл большую роль. После инцидента с самолётом Су-24 (24 ноября 2015 г.) отношения между государствами резко испортились. Турция уничтожила российский самолёт в Сирии, что вызвало резко негативную реакции со стороны России. Это привело к значительному ухудшению российско-турецкий отношений. Это коснулось и энергетического сектора.

Совместный проект «Турецкий поток» оказался на гране разрыва. 27 января 2015 в Анкаре по итогам встречи Алексея Миллера и Танера Йылдыза, министра энергетики и природных ресурсов Турции, был определён маршрут «Турецкого потока». Однако 26 ноября 2015, через 2 дня после инцидента с самолётом Су-24, было объявлено, что Россия прекращает работу над рядом совместных проектов, и 3 декабря было официально объявлено о приостановлении проекта «Турецкий поток».

Потепление отношений произошло через 15 месяцев. 27 июня 2016 года Президент Турции Реджеп Тайип Эрдоган в послании президенту РФ Владимиру Путин извинился за сбитый турецкими войсками в Сирии. И уже через месяц, а именно 26 июля, Аркадий Дворкович, заместитель председателя Правительства Российской Федерации, заявил, что Турция готова возобновить реализацию проекта «Турецкий поток». В сентябре «Газпром» получил первое разрешение на подготовительные процедуры по возобновлению проекта.

Таблица 2. Объёмы поставок газа из России в Турцию, млрд. $\mathbf{м}^{3}$

\begin{tabular}{|c|c|c|c|c|c|c|}
\hline Год & 2005 & 2006 & 2010 & 2011 & 2014 & 2016 \\
\hline Объём газа & Более 18 & Около 20 & 18 & 26 & 27,4 & 23,2 \\
\hline
\end{tabular}

Источник: составлено автором по данным компании «Газпром» [6] 
В мае 2010 года после визита Дмитрия Медведева, президента России 2008-2012 гг., в Турции было подписано соглашение о сотрудничестве двух государств о строительстве и эксплуатации атомной электростанции. В соответствии с ним будет построена АЭС «Аккую» на южном побережье Турции. Предполагается, что турецкие специалисты примут непосредственное участие в эксплуатации станции на всех этапах её жизненного цикла. Для реализации данной цели 27 июня 2011 г. в Анкаре совместно с преподавателями Национального исследовательского ядерного университета (МИФИ) прошло тестирование знаний турецких абитуриентов по таким предметам, как физика и математика. На программу обучения, которая предусматривает набор 50 турецких студентов, поступило более 9000 заявок. В 2018 году в МИФИ обучалось свыше 250 турецких граждан. В соответствии с соглашением турецкие специалисты войдут в состав персонала, эксплуатирующего атомную электростанцию «Аккую», после получения ими соответствующего образования и прохождения обучения в учебно-технических центрах «Росатома. Это ещё один пример кооперации двух государств.

В результате обострения отношений между Россией и Турцией в конце 2015 года (как уже было отмечено выше, они ухудшились после уничтожения турецкими войсками российского самолета Су-24) появились опасения, что проект может быть приостановлен [2, стр. 106]. Однако 19 апреля 2016 года президент Турции Реджеп Тайип Эрдоган заявил, что Турция не намерена отказываться от проекта, несмотря на давление со стороны Европейского Союза. И уже в августе 2016 года главы государств России и Турции договорились о возобновлении проекта АЭС «Аккую».

Директор Международного института новейших государств Алексей Мартынов отметил, что проект возведения АЭС «Аккую» имеет не только экономическое, но и политическое значение: «Проект предусматривает совместную эксплуатацию строящейся АЭС и, в дальнейшем, совместное получение прибыли. Но, конечно, это не только крайне выгодный для России и Турции экономический проект. Это и важный политический проект по расширению и углублению и без того динамично развивающихся российско-турецких отношений» [7].

Однако контракт по строительству АЭС «Аккую» на территории Турции весьма слож- но назвать выгодным для России. Во-первых, с турецкой стороны отсутствуют финансовые обязательства. Это означает, что все расходы будут оплачены российской стороной из государственного бюджета. Во-вторых, цена на энергию, выработанной на АЭС «Аккую», зафиксирована в контракте на 25 лет [9]. Стоит отметить, что при такой фиксации не учитывается изменение цены в результате инфляции доллара, роста мировых цен на электроэнергию, а также изменения курса валют. В-третьих, в соглашении не прописаны форс-мажорные обстоятельства, а также не указан запрет на национализацию Турцией атомной электростанцией.

Таким образом, Россия идёт на большие риски, так как строительство может окупиться только через несколько десятков лет. Более того, когда АЭС начнёт эксплуатироваться и юг страны будет обеспечивать электроэнергией, выработанной на АЭС «Аккую», позиции «Газпрома» могут быть подорваны как самого крупного поставщика газа в Турцию.

Действия российской стороны можно объяснить. Россия идёт на уступки, так как, в первую очередь, Турция вот уже 10 лет является вторым крупнейшим (после Германии) покупателем российского газа. Соглашение по строительству АЭС «Аккую» означает реализацию проекта «Турецкий поток». Контракт весьма выгоден и для «Росатома», так как Турция - новый рынок сбыта высокотехнологической продукции.

Таким образом, с начала XXI века в отношениях между Россией и Турцией отчётливо видны переходы от кооперации к кооптации и возвращению к кооперации. Несмотря на похолодание отношений в 2015 году, взаимодействие двух государств остаётся на высоком уровне. Со своей стороны Россия идёт на многие уступки, так как Турция - важный партнёр в области реализации энергетических проектов. Возможно, что в отношениях между государствами вновь наступит кризис, что приведёт вновь к конфронтации, в том числе и в энергетическом комплексе. Для сокращения рисков Российской стороне следует реализовывать проекты в энергетической сфере не только с Турцией, но и с другими государствами, диверсифицируя тем самым партнёров. Всё же взаимоотношения России и Турции с каждым новым проектом укрепляются, простой пример тому - практически реализованный газопровод «Турецкий поток», ввод в эксплуатацию которого намечен на конец 2019 года. 


\section{Библиографический список}

1. Гниломёдов E.В. Особенности энергетического сотрудничества России и Турции в условиях изменения энергосистемы Европейского союза. Москва. 2015. С. 20-81.

2. Оздемир В., Гулиев И.А. Энергетическая дипломатия Турции. // Вестник МГИМО Университета. 2016. С. 102107.

3. Шангараев Р.Н. Взаимодействие России и Турции в сфере энергетики. / Турция: новые реалии во внутренней политике и участие в региональных геополитических процессах. М., 2014. C 241-250.

4. Шлыков П.В., Ульченко Н.Ю. Динамика российско-турецких отношений в условиях нарастания глобальной нестабильности. Москва. 2014. С. 48-61.

5. Официальный сайт компании ВР. Статистика https://www.bp.com/

6. Официальный сайт компании «Газпром». http://www.gazprom.ru/

7. Информационное агентство РИА новости. https://ria.ru/

8. Информационное агентство России ТАСC. http://tass.ru/

9. Официальный сайт проекта «Аккую» http://www.akkunpp.com 